\title{
KINERJA KEUANGAN PADA KOPERASI PENERIMA DANA BERGULIR MODAL KERJA DI DAERAH ISTIMEWA YOGYAKARTA Studi Kasus pada Koperasi Serba Usaha (KSU) BMT An Ni'mah Kotagede
}

\author{
Siti Mubiroh \\ Beni Suhendra Winnarso
}

\begin{abstract}
Empowerment of cooperatives is part of poverty reduction through the expansion of employment opportunities and the increase of society incomes. In the framework of economic empowerment and cooperatives income increasing in DIY, the provincial government provide Dana Bergulir Modal Kerja to increase the production capacity of the cooperative.The objective of this research is to analyze the financial performance of cooperatives before and after receiving Dana Bergulir Modal Kerja. The main data that was collected is secondary data. The financial data was analyzed using quantitave analysis using financial ratio analysis and different t-test (paired sample t test). Result of analysis showed that there are some increases in debt to total asset ratio and there is no increase in current ratio, cash ratio, net profit margin ratio, return on asset ratio and return on equity ratio in KSU BMT An Ni'mah Kotagede after receiving Dana Bergulir Modal Kerja.
\end{abstract}

Keyword: Dana Bergulir Modal Kerja, current ratio, cash ratio, total debt to total asset ratio, net profit margin ratio, return on asset ratio, return on equity ratio.

\section{PENDAHULUAN}

Koperasi merupakan perkumpulan orang yang secara sukarela mempersatukan diri untuk memperjuangkan peningkatan kesejahteraan ekonomi mereka, melalui pembentukan sebuah badan usaha yang dikelola secara demokratis (Rudianto, 2006: 1). Koperasi bertujuan memajukan kesejahteraan anggota pada khususnya dan masyarakat padaumumnya serta ikut membangun tatanan perekonomian Nasional dalam rangka mewujudkanmasyarakat yang maju , adil, dan makmur berlandaskan Pancasila dan Undang-undang Dasar 1945 (Undang-Undang Nomor 25 Tahun 1992). Terdapat alasan mendasar bagi sebuah negara berkembang dalam memandang pentingnya keberadaan koperasi adalah: (1) Membangun dan mengembangkan potensi dan kemampuan ekonomi anggota pada khususnya dan masyarakat pada umumnya untuk meningkatkan kesejahteraan ekonomi dan 
sosialnya, (2) Berperan serta secara aktif dalam upaya mempertinggi kualitas kehidupan masyarakat, (3) Memperkokoh perekonomian rakyat sebagai dasar kekuatan dan ketahanan perekonomian nasional dengan koperasi sebagai sokogurunya, dan (4) Berusaha mewujudkan dan mengembangkan perekonomian nasional yang merupakan usaha bersama berdasar atas asas kekeluargaan dan demokrasi ekonomi.

Data yang diperoleh dari Dinas Perindustrian, Perdagangan, Koperasi dan UKM Daerah Istimewa Yogyakarta menunjukkan bahwa sampai september 2013 jumlah koperasi di DIY mencapai 2500 unit. Hal ini berarti koperasi memiliki kontribusi yang sangat besar bagi perekonomian di Indonesia khususnya di DIY. Pemberdayaan koperasi merupakan bagian dalam penanggulangan kemiskinan melalui perluasan kesempatan kerja dan peningkatan pendapatan masyarakat. Dalam rangka pemberdayaan ekonomi dan peningkatan pendapatan koperasi di DIY, maka pemerintah propinsi DIY memberikan kredit modal kerja guna meningkatkan kemampuan berproduksi bagi koperasi. Potensi koperasi di DIY memiliki peranan yang cukup besar terhadap pembangunan daerah apabila dikembangkan secara efektif melalui usaha ekonomi yang produktif, atas dasar tersebut, pemerintah DIY melalui dana APBD tahun 2010 mengalokasikan dana untuk pemberdayaan koperasi melalui program Dana Bergulir Modal Kerja.

Penilaian kinerja dana bergulir ini akan terlihat dari perbandingan kinerja keuangan sebelum dan sesudah mendapat bantuan dana bergulir. Oleh karena itu penelitian ini difokuskan pada kinerja keuangan pada koperasi penerima dana bergulir modal kerja di Daerah Istimewa Yogyakarta, studi kasus pada Koperasi Serba Usaha (KSU) BMT An Ni'mah Kotagede.

\section{TINJAUAN PUSTAKA}

\section{Kinerja}

Pengukuran kinerja adalah pengukuran atas hasil dari implementasi strategi, ukuran ini dapat dilihat sebagai faktor keberhasilan masa kini dan masa depan. Jika ukuran-ukuran ini membaik, berarti perusahaan telah mengimplementasikan strateginya. Sistem ukuran kinerja hanyalah merupakan suatu mekanisme yang 
memperbaiki kemungkinan bahwa organisasi tertsebut akan mengimplementasikan strateginya dengan berhasil (Anthony \& Govindarajan, 2005: 169).

\section{Laporan keuangan.}

Menurut Munawir (2002: 267) laporan keuangan merupakan alat yang sangat penting untuk memperoleh informasi sehubungan dengan posisi keuangan dan hasil-hasil operasi yang telah dicapai oleh perusahaan yang bersangkutan. Informasi tersebut dapat digunakan sebagai dasar pengambilan keputusan ekonomik, baik oleh pihak manajemen maupun pihak ekstern.

\section{Kinerja Keuangan}

Informasi dan gambaran perkembangan keuangan perusahaan bisa diperoleh dengan mengadakan interpretasi dari laporan keuangan, yakni dengan menghubungkan elemen-elemen yang ada pada laporan keuangan seperti elemenelemen dari berbagai aktiva satu dengan lainnya, elemen-elemen pasiva yang satu dengan lainnya, elemen aktiva dengan pasiva, elemen-elemen neraca dengan elemen-elemen laporan rugi/laba, akan bisa diperoleh banyak gambaran mengenai kondisi keuangan suatu perusahaan (Sutrisno, 2009: 212).

\section{Alat Ukur Kinerja Keuangan.}

Menurut Munawir (2002: 268) dalam menganalisis dan menilai posisi keuangan, kemajuan-kemajuan, serta potensi di masa mendatang, faktor utama yang umumnya mendapatkan perhatian oleh para analis adalah:

1. Likuiditas, yang menunjukkan kemampuan perusahaan untuk memenuhi kewajiban keuangan yang harus segera dipenuhi dalam jangka pendek atau pada saat jatuh tempo.

2. Solvabilitas, yaitu kemampuan perusahaan untuk memenuhi semua kewajibannya, baik jangka pendek maupun jangka panjang, apabila perusahaan tersebut dilikuidasi.

3. Profitabilitas, yang menunjukkan kemampuan perusahaan untuk menghasilkan laba dalam perioda tertentu. 
4. Aktivitas, rasio aktivitas mengukur seberapa besar efektivitas perusahaan dalam memanfaatkan sumber dananya.

\section{Koperasi}

Koperasi adalah badan usahayang beranggotakan orang-seorang atau badan hokum koperasi dengan melandaskan kegiatannya berdasarkan prinsip Koperasi sekaligus sebagai gerakan ekonomi rakyat yang berdasar atas asas kekeluargaan (Undang-Undang Nomor 25 Tahun 1992). Koperasi adalah suatu perkumpulan yang didirikan oleh orang-orang yang memiliki kemampuan ekonomi terbatas, yang bertujuan untuk memperjuangkan peningkatan kesejahteraan ekonomi mereka (Rudianto, 2006: 2).

\section{Dana Bergulir}

Menurut Peraturan Menteri Keuangan Nomor 218 Tahun 2009, dana bergulir adalah dana yang dialokasikan oleh kementrian Negara/Lembaga/Satuan Kerja Badan Layanan Umum untuk kegiatan perkuatan modal usaha bagi Koperasi, Usaha Mikro, Kecil, Menengah, dan usaha lainnya yang berada di bawah pembinaan Kementerian Negara/Lembaga.

\section{PENGEMBANGAN HIPOTESIS}

\section{Current Ratio}

Hasil penelitian Setiawan dan Rejekiningsing (2009) terdapat penambahan modal usaha sekitar $28,57 \%$ bagi setiap usaha kecil dan menengah (UKM) sesudah memperoleh pinjaman kredit, omset penjualan setiap UKM rata-rata mengalami peningkatan sebesar 33\%. Hal tersebut secara otomatis menambah aktiva lancar yang dapat digunakan untuk membayar utang jangka pendek perusahaan. Penelitian Burhannudin (2006) menunjukkan hasil current ratio pada koperasi adalah $188 \%$. Hasil tersebut mengilustrasikan suatu kinerja finansial yang tergolong baik setelah menerima dana bergulir.

$\mathrm{H}_{1}$ : Terdapat peningkatan current ratio pada KSU BMT An Ni'mah sesudah menerima dana bergulir modal kerja. 


\section{Cash Ratio}

Hasil penelitian Setiawan dan Rejekiningsing (2009) omset penjualan setiap usaha kecil menengah rata-rata mengalami peningkatan sebesar 33\%. Hasil penelitian Surya (2011) menunjukkan bahwa hasil yang berbeda didapatkan pada cash ratio yang digunakan untuk mengukur jumlah kas tersedia dibanding dengan utang lancar. Adanya perubahan cash ratio yang signifikan disebabkan kenaikan penjualan yang menghasilkan kas yang lebih besar. Adanya penyaluran dana bergulir akan memungkinkan perusahaan untuk menambah modal kerja dan meningkatkan penjualan. Peningkatan penjualan akan mempengaruhi ketersediaan kas yang bisa digunakan untuk pembayaran utang.

$\mathrm{H}_{2}$ : Terdapat peningkatan cash rasio pada KSU BMT An Ni'mah sesudah menerima dana bergulir modal kerja.

\section{Total Debt to Total Asset Ratio.}

Penelitian Burhannudin (2006) menunjukkan hasil rasio utang sebesar 68\%. Hasil tersebut mengilustrasikan suatu kinerja finansial yang tergolong cukup baik setelah menerima dana bergulir.

$\mathrm{H}_{3}$ : Terdapat peningkatan Total Debt to Total Asset Ratio pada KSU BMT An Ni'mah sesudah menerima dana bergulir modal kerja.

\section{Net Profit Margin}

Penelitian yang dilakukan oleh Susiana (2010) menunjukkan bahwa terdapat perbedaan NPM sesudah penerimaan dana bergulir. Penelitian Ibrahim dan Hapsari (2009) menunjukkan terdapat perbedaan net profit margin sebelum dan sesudah menerima dana bergulir modal kerja. Burhannudin (2006) menunjukkan hasil rasio laba sebesar 91\%. Hasil tersebut mengilustrasikan suatu kinerja finansial yang tergolong baik setelah menerima dana bergulir. Hasil penelitian Surya (2011) menunjukkan bahwa rasio profitabilitas yang mengalami perubahan signifikan adalah NPM. Hal ini terjadi karena adanya bantuan dana bergulir yang menyebabkan naiknya penjualan perusahaan sehingga dapat meningkatkan laba bersih usaha. Adanya perbedaan ini juga dikaitkan dengan meningkatnya ketersediaan kas yang ditunjukan oleh cash ratio yang juga mengalami perubahan 
yang signifikan, yang sebagiannya merupakan laba yang dihasilkan. Hasil penelitian Setiawan dan Rejekiningsih (2009) keuntungan yang diperoleh setiap usaha kecil dan menengah rata-rata meningkat lebih dari 50\%. Hal tersebut menunjukkan bahwa setelah memperoleh pinjaman kredit rata-rata tingkat profitabilitas usaha kecil dan menengah lebih tinggi daripada sebelum memperoleh pinjaman kredit.

$\mathrm{H}_{4}$ : Terdapat peningkatan net profit margin pada KSU BMT An Ni'mah sesudah menerima dana bergulir modal kerja.

\section{Return on Asset.}

Pada penelitian yang dilakukan oleh Susiana (2010) yang menunjukkan bahwa terdapat perbedaan ROA sesudah penerimaan dana bergulir. Hasil penelitian Surya (2011) menunjukkan adanya perubahan ROA dapat membuktikan bahwa penggunaan dana bergulir dalam penambahan aktiva telah mampu membuat laba bersih dari usaha tersebut berubah. Terjadinya perubahan ini karena adanya peningkatan laba bersih sebagai dampak dari penambahan aktiva produktif.

$\mathrm{H}_{5}$ : Terdapat peningkatan return on asset pada KSU BMT An Ni'mah sesudah menerima dana bergulir modal kerja.

\section{Return on Equity.}

Penelitian yang dilakukan oleh Susiana (2010) menunjukkan bahwa terdapat perbedaan ROE sesudah penerimaan dana bergulir. Penelitian Burhannudin (2006) menunjukkan hasil return on equity ratio sebesar 53,15\%. Hasil tersebut mengilustrasikan suatu kinerja finansial yang tergolong cukup baik setelah menerima dana bergulir.

$\mathrm{H}_{6}$ : Terdapat peningkatan return on equity pada KSU BMT An Ni'mah sesudah menerima dana bergulir modal kerja.

\section{Model Penelitian}

Berdasar latar belakang, landasan teori, dan penelitian terdahulu maka peneliti membuat model penelitian sebagai berikut: 


\begin{tabular}{|l|l|l|}
\hline $\begin{array}{l}\text { Kinerja keuangan } \\
\text { sebelum menerima dana } \\
\text { bergulir modal kerja }\end{array}$ & Uji Beda & $\begin{array}{l}\text { Kinerja keuangan } \\
\text { setelah menerima dana } \\
\text { bergulir modal kerja }\end{array}$ \\
\cline { 3 - 3 } & & \\
\hline
\end{tabular}

\section{Gambar 1 \\ Model penelitian}

\section{METODA PENELITIAN}

\section{Objek Penelitian}

Penelitian ini mengacu pada laporan keuangan KSU BMT An Ni'mah Kotagede dengan menganalisis dalam kurun waktu dua tahun sebelum menerima dana bergulir modal kerja yaitu tahun 2008, 2009 dan dua tahun sesudah menerima dana bergulir modal kerja yaitu tahun 2011, 2012.

Jenis data yang digunakan dalam penelitian ini adalah data sekunder berupa laporan posisi keuangan dan laporan laba/rugi sebelum menerima dana bergulir modal kerja yaitu tahun 2008, 2009 dan sesudah menerima dana bergulir modal kerja yaitu tahun 2011, 2012. Data tersebut diperoleh langsung dari KSU BMT An Ni'mah Kotagede.

\section{Definisi Variabel dan Pengukuran Variabel}

\section{Current Ratio}

Current ratio adalah rasio yang membandingkan antara aktiva lancar yang dimiliki perusahaan dengan utang jangka pendek. Aktiva lancar di sini meliputi kas, piutang dagang, efek, persediaan, dan aktiva lancar lainnya. Sedangkan utang jangka pendek meliputi utang dagang, utang wesel, utang bank, utang gaji, dan utang lainnya yang segera harus dibayar (Sutrisno,2009: 216). Rumus current ratio adalah:

Current Ratio: $\quad$ Aktiva Lancar $\times 100 \%$

\section{Utang Lancar}

\section{Cash ratio}

Cash ratio adalah rasio yang membandingkan antara kas dan aktiva lancar yang bisa segera menjadi uang kas dengan utang lancar. Aktiva lancar yang bisa 
segera menjadi uang kas adalah efek atau surat berharga (Sutrisno, 2009:216). Rumus cash ratio adalah:

\section{Cash Ratio: : $\quad$ Kas + Sekuritas $\times 100 \%$ \\ Utang Lancar}

\section{Total Debt to Total Asset Ratio.}

Rasio total utang dengan rasio total aktiva yang biasa disebut rasio utang (debt ratio), mengukur prosentasi besarnya dana yang berasal dari utang, yang dimaksud dengan utang adalah semua utang yang dimiliki oleh perusahaan baik yang berjangka pendek maupun yang berjangka panjang. Kreditor lebih menyukai debt ratio yang rendah sebab tingkat keamanan dananya menjadi semakin baik (Sutrisno, 2009: 217). Debt ratio dapat dihitung dengan menggunakan rumus:

\section{Debt Ratio: : $\quad$ Total Utang x 100\%}

\section{Total Aktiva}

\section{Net Profit Margin}

Net profit margin merupakan kemampuan perusahaan untuk menghasilkan keuntungan dibandingkan dengan penjualan yang dicapai (Sutrisno,2009: 222). Rumus yang digunakan adalah:

Net Profit Margin: $\frac{\text { EAT }}{\text { Penjualan }} \times 100 \%$

\section{Return on Asset}

Return on asset merupakan ukuran kemampuan perusahaan dalam menghasilkan laba dengan semua aktiva yang dimiliki oleh perusahaan. Dalam hal ini laba yang dihasilkan adalah laba sebelum bunga dan pajak atau EBIT (Sutrisno,2009: 222). Rumus ROA yang digunakan adalah:

Return on Asset: $\frac{\text { EBIT }}{\text { TotalAktiva }} \times 100 \%$

\section{Return on Equity}

Return on equity yaitu kemampuan perusahaan dalam menghasilkan keuntungan dengan modal sendiri yang dimiliki, sehingga ROE ini ada yang menyebut sebagai rentabilitas modal sendiri. Laba yang diperhitungkan adalah laba 
bersih setelah pajak atau EAT (Sutrisno, 2009: 223). Rumus yang digunakan adalah:

Return on Equity: $\frac{\text { EAT }}{\text { ModalSendiri }} \times 100 \%$

\section{Teknik Analisis Data}

\section{Uji Normalitas Data}

Uji normalitas data adalah alat analisis untuk mengetahui bahwa suatu data berasal dari populasi yang sama. Jika data berdistribusi normal maka statistik yang digunakan adalah statistik parametrik dan jika data berdistribusi tidak normal maka data akan diolah menggunakan statistik non parametrik sehingga uji normalitas digunakan untuk mengetahui data tersebut berdistribusi normal atau tidak. Penelitian ini menggunakan uji normalitas data yang menggunakan alat uji one sample kolmogorov smirnov. Kriteria yang digunakan dalam pengambilan keputusan pada pengujian one sample kolmogorov smirnov adalah:

a. Jika nilai signifikansi < 0,05 (alpha) maka data berdistribusi tidak normal.

b. Jika nilai signifikansi > 0,05 (alpha) maka data berdistribusi normal.

\section{Uji hipotesis}

Menurut Kurniawati (2011: 26) uji t sampel berpasangan (paired sample ttest) digunakan untuk pengujian hipotesis dengan data yang berdistribusi normal. Sedangkan data yang berdistribusi tidak normal maka pengujian hipotesismya menggunakan alat uji non-parametrik Wilcoxon signed rank test. Kriteria yang digunakan dalam pengambilan keputusan pada pengujian hipotesis adalah:

a. Jika nilai 2-tailed $<0,05$ maka hipotesis tidak dapat ditolak.

b. Jika nilai 2-tailed $>0,05$ maka hipotesis ditolak.
Atau
c. Jika t hitung (angka t pada output) $>\mathrm{t}$ tabel, maka hipotesis tidak dapat ditolak.
d. Jika t hitung (angka t pada output) $<\mathrm{t}$ tabel, maka hipotesis ditolak. 


\section{PEMBAHASAN}

\section{Analisis Deskriptif}

\section{Tabel 1}

Perbandingan rata-rata kinerja keuangan perioda sebelum dan sesudah menerima dana bergulir modal kerja

\begin{tabular}{|c|l|r|r|}
\hline No & \multicolumn{1}{|c|}{ Kinerja keuangan } & Rata-rata sebelum & Rata-rata sesudah \\
\hline 1 & Current ratio & 116,80 & 115,84 \\
\hline 2 & Cash ratio & 33,89 & 30,85 \\
\hline 3 & Total debt to total asset ratio & 94,85 & 94,48 \\
\hline 4 & Net profit margin & 16,23 & 7,17 \\
\hline 5 & Return on asset & 5,79 & 6,37 \\
\hline 6 & Return on equity & 34,06 & 16,53 \\
\hline
\end{tabular}

Sumber: Data sekunder, diolah (2014)

Tabel 1 menunjukkan perbandingan rata-rata kinerja keuangan dapat dilihat besarnya current ratio sebelum menerima dana bergulir modal kerja adalah 116,80 dari perhitungan tersebut dapat disimpulkan bahwa setiap Rp 1,- utang lancar dijamin dengan Rp116,80 aktiva lancar, dan besarnya current ratio setelah menerima dana bergulir modal kerja menjadi 115,84 yang artinya setiap Rp1,utang lancar dijamin dengan Rp115,84 aktiva lancar. Besarnya rata-rata cash ratio sebelum menerima dana bergulir modal kerja sebesar 33,89. Dari perhitungan tersebut dapat disimpulkan bahwa setiap Rp1,- utang lancar dijamin dengan Rp33,89 uang kas dan yang segera menjadi kas, dan besarnya cash ratio setelah menerima dana bergulir modal kerja menjadi 30,85 yang artinya setiap Rp1,- utang lancar dijamin dengan Rp30,85 uang kas dan yang segera menjadi kas.

Besarnya rata-rata debt ratio sebelum menerima dana bergulir modal kerja sebesar 94,85\% yang artinya aktiva perusahaan sebesar 94,85\% dibelanjai oleh utang, dan besarnya debt ratio setelah menerima dana bergulir modal kerja menjadi 94,48\% yang artinya aktiva perusahaan sebesar 94,48\% dibelanjai oleh utang. Besarnya rata-rata net profit margin ratio sebelum menerima dana bergulir modal kerja adalah 16,23. Dari perhitungan tersebut berarti perusahaan mampu menghasilkan laba sebesar $16,23 \%$ dari penjualan, dan besarnya net profit margin ratio setelah menerima dana bergulir modal kerja menjadi 7,17 yang artinya perusahaan mampu menghasilkan laba sebesar 7,17\% dari penjualan. 
Besarnya rata-rata return on asset ratio sebelum menerima dana bergulir modal kerja adalah 5,79. Berdasar perhitungan tersebut berarti bahwa perusahaan mampu menghasilkan tingkat laba sebesar 5,79\% dari aktiva yang digunakan, dan besarnya return on asset ratio setelah menerima dana bergulir modal kerja menjadi 6,37 yang artinya perusahaan mampu menghasilkan laba sebesar 6,37\% dari aktiva yang digunakan. Besarnya rata-rata return on equity sebelum menerima dana bergulir modal kerja adalah 34,06. Perhitungan tersebut menunjukan bahwa perusahaan mampu menghasilkan laba sebesar 34,06\% dari modal sendiri, dan besarnya return on equity ratio setelah menerima dana bergulir modal kerja menjadi 16,53 yang artinya perusahaan mampu menghasilkan laba sebesar $16,53 \%$ dengan menggunakan modal sendiri.

\section{Uji Normalitas Data}

Tabel 2

Ringkasan Uji Normalitas Data

\begin{tabular}{|c|l|c|c|c|}
\hline No & Kinerja keuangan & $\begin{array}{c}\text { Asymp sig. } \\
\text { sebelum }\end{array}$ & $\begin{array}{c}\text { Asymp sig. } \\
\text { sesudah }\end{array}$ & Simpulan \\
\hline 1 & Current ratio & 0,999 & 0,999 & Normal \\
\hline 2 & Cash ratio & 0,999 & 0,999 & Normal \\
\hline 3 & Total debt to total asset ratio & 0,999 & 0,999 & Normal \\
\hline 4 & Net profit margin & 0,999 & 0,999 & Normal \\
\hline 5 & Return on asset & 0,999 & 0,999 & Normal \\
\hline 6 & Return on equity & 0,999 & 0,999 & Normal \\
\hline
\end{tabular}

Sumber: Data sekunder, diolah (2014)

Uji normalitas data menunjukkan bahwa rata-rata semua rasio berdistribusi normal karena Asym. Sig 0,999 > 0,05.

\section{Hasil Uji Hipotesis}

Setelah dilakukan uji normalitas data didapatkan data berdistribusi normal sehingga untuk uji hipotesisnya menggunakan paired sample t-test dengan pengambilan keputusan Jika nilai sig. (2-tailed) $<0,05$ maka hipotesis tidak dapat ditolak dan jika nilai sig. (2-tailed) $>0,05$ maka hipotesis ditolak atau Jika t hitung (angka t pada output) $>\mathrm{t}$ tabel maka hipotesis tidak dapat ditolak. Jika $\mathrm{t}$ hitung 
(angka $\mathrm{t}$ pada output) $<\mathrm{t}$ tabel maka hipotesis ditolak. Besarnya $\mathrm{t}$ tabel dalam penelitian ini adalah 6,3138 $(\alpha=0,05, \mathrm{df}=1)$. Ringkasan hasil uji hipotesis dapat dilihat pada tabel berikut:

Tabel 3

Ringkasan Hasil uji Hipotesis

\begin{tabular}{|l|l|l|r|l|}
\hline No & Kinerja keuangan & $\begin{array}{l}\text { Asymp. } \\
\text { Sig. }\end{array}$ & t hitung & Simpulan \\
\hline 1 & Current ratio & 0,786 & 0,349 & $\mathrm{H}_{1}$ ditolak \\
\hline 2 & Cash ratio & 0,778 & 0,364 & $\mathrm{H}_{2}$ ditolak \\
\hline 3 & Total debt to total asset ratio & 0,035 & 18,300 & $\mathrm{H}_{3}$ diterima \\
\hline 4 & Net profit margin & 0,229 & 2,661 & $\mathrm{H}_{4}$ ditolak \\
\hline 5 & Return on asset & 0,120 & 5,235 & $\mathrm{H}_{5}$ ditolak \\
\hline 6 & Return on equity & 0,338 & 1,700 & $\mathrm{H}_{6}$ ditolak \\
\hline
\end{tabular}

Hasil uji hipotesis yang telah dikemukakan sebelumnya, untuk current ratio besarnya thitung 0,349 lebih kecil dari t tabel 6,3138, sehingga dapat disimpulkan bahwa $\mathrm{H}_{1}$ ditolak yang artinya tidak terdapat peningkatan current ratio pada KSU BMT An Ni'mah sesudah menerima dana bergulir modal kerja. Hasil uji hipotesis untuk cash ratio besarnya t hitung 0,364 lebih kecil dari t tabel 6,3138, sehingga dapat disimpulkan bahwa $\mathrm{H}_{2}$ ditolak yang artinya tidak terdapat peningkatan cash ratio pada KSU BMT An Ni'mah sesudah menerima dana bergulir modal kerja. Data di lapang diketahui bahwa rata-rata nilai aktiva lancar dan utang lancar pada KSU BMT An Ni'mah mengalami peningkatan di tahun setelah penerimaan dana bergulir modal kerja. Namun perlu diperhatikan bahwa kenaikan yang terjadi pada kedua komponen keuangan tersebut tidak sama, dan rata-rata kenaikan yang dialami oleh utang lancar koperasi lebih besar dibandingkan dengan kenaikan yang dialami oleh aktiva lancar, sehingga mengakibatkan rata-rata nilai current ratio menjadi turun, dan hal yang sama terjadi pada penurunan cash ratio yang terjadi akibat adanya kenaikan lebih besar pada komponen utang lancar yang menjadi bilangan penyebut.

Hasil uji hipotesis untuk total debt ratio besarnya thitung 18,300 lebih besar dari t tabel 6,3138, sehingga dapat disimpulkan bahwa $\mathrm{H}_{3}$ diterima yang artinya terdapat peningkatan total debt ratio pada KSU BMT An Ni'mah sesudah menerima dana bergulir modal kerja. Data di lapangan diketahui bahwa rata-rata 
nilai total aktiva dan total utang pada KSU BMT An Ni'mah mengalami peningkatan ditahun setelah penerimaan dana bergulir modal kerja yang artinya aktiva perusahaan yang dibelanjai oleh utang lebih tinggi dibandingkan dengan sebelum penerimaan dana bergulir modal kerja, hal ini disebabkan adanya dana bergulir modal kerja yang termasuk jenis utang jangka panjang sehingga meningkatkan jumlah rupiah pada bilangan pembilang yaitu total utang.

Hasil uji hipotesis untuk net profit margin ratio nilai besarnya t hitung 2,661 lebih kecil dari t tabel 6,3138, sehingga dapat disimpulkan bahwa $\mathrm{H}_{4}$ ditolak yang artinya tidak terdapat peningkatan net profit margin ratio pada KSU BMT An Ni'mah sesudah menerima dana bergulir modal kerja. Data di lapangan diketahui bahwa rata-rata nilai EAT dan penjualan pada KSU BMT An Ni'mah mengalami peningkatan di tahun setelah penerimaan dana bergulir modal kerja. Namun kenaikan yang terjadi pada kedua komponen keuangan tersebut tidak sama, dan rata-rata kenaikan yang dialami oleh penjualan perusahaan lebih besar dibandingkan dengan kenaikan yang dialami oleh EAT, sehingga mengakibatkan rata-rata nilai net profit margin menjadi turun, disamping itu, penurunan yang timbul merupakan akibat dari peningkatan biaya operasional yang menjadi salah satu faktor utama adanya penurunan nilai pada EAT.

Hasil uji hipotesis untuk return on asset ratio besarnya t hitung 5,235 lebih kecil dari t tabel 6,3138, sehingga dapat disimpulkan bahwa $\mathrm{H}_{5}$ ditolak yang artinya tidak terdapat peningkatan return on asset ratio pada KSU BMT An Ni'mah sesudah menerima dana bergulir modal kerja. Data di lapangan diketahui bahwa rata-rata nilai EBIT dan total aktiva pada KSU BMT An Ni'mah mengalami peningkatan di tahun setelah penerimaan dana bergulir modal kerja. Namun kenaikan yang terjadi pada kedua komponen keuangan tersebut tidak sama, dan rata-rata kenaikan yang dialami oleh total aktiva perusahaan lebih besar dibandingkan dengan kenaikan yang dialami oleh EBIT, sehingga mengakibatkan rata-rata nilai return on asset ratio menjadi turun. Kenaikan total aktiva sesudah penerimaan dana bergulir modal kerja disebabkan peningkatan yang cukup tinggi pada aktiva lancar dan investasi. 
Hasil uji hipotesis untuk return on equity ratio besarnya t hitung 1,700 lebih kecil dari t tabel 6,3138, sehingga dapat disimpulkan bahwa $\mathrm{H}_{6}$ ditolak yang artinya tidak terdapat peningkatan return on equity ratio pada KSU BMT An Ni'mah sesudah menerima dana bergulir modal kerja. Data di lapangan diketahui bahwa rata-rata nilai EAT dan modal sendiri pada KSU BMT An Ni'mah mengalami peningkatan di tahun setelah penerimaan dana bergulir modal kerja. Namun kenaikan yang terjadi pada kedua komponen keuangan tersebut tidak sama, dan rata-rata kenaikan yang dialami oleh modal sendiri perusahaan lebih besar dibandingkan dengan kenaikan yang dialami oleh EAT, sehingga mengakibatkan rata-rata nilai return on equity ratio menjadi turun. Kenaikan modal sendiri sesudah penerimaan dana bergulir modal kerja disebabkan oleh peningkatan jumlah anggota koperasi.

\section{SIMPULAN, KETERBATASAN, DAN SARAN}

Simpulan dari penelitian ini adalah terdapat peningkatan total debt to total asset ratio pada KSU BMT An Ni'mah sesudah menerima dana bergulir modal kerja dan tidak terdapat peningkatan current ratio, cash ratio, net profit margin ratio, return on asset ratio, dan return on equity ratio pada KSU BMT An Ni'mah sesudah menerima dana bergulir modal kerja.

penelitian ini memiliki keterbatasan yaitu laporan keuangan yang diberikan oleh koperasi berupa laporan keuangan tahunan sehingga hanya terdapat dua data laporan keuangan sebelum dan sesudah menerima dana bergulir modal kerja. Oleh karena itu, untuk penelitian selanjutnya disarankan menggunakan data laporan keuangan bulanan atau triwulan sehingga mendapatkan informasi mengenai kinerja keuangan koperasi secara detail.

\section{DAFTAR PUSTAKA}

Anthony, Robert N dan Govindarajan Vijay. 2005. Management Control System. Jakarta: Salemba Empat

Burhanuddin. 2006. "Evaluasi Program Bantuan Dana Bergulir Melalui KSP/USP Koperasi (Pola PKPS-BBM, Agribisnis dan Syariah)". Jurnal pengkajian Koperasi dan UKM Nomor 1 Tahun I- 2006. 
Hanafi, Mamduh. 2005. Manajemen Keuangan. Yogyakarta: BPFE UGM.

Hanafi, Mamduh dan Halim, dkk. 2005. Analisis Laporan Keuangan. Yogyakarta: YPKN

Ibrahim, Jabal Tarik dan Hanif Fitria Hapsari. 2009. "Kinerja Keuangan Pada Usaha Keci Menengah Penerima Dana Bergulir Modal Kerja di Kabupaten Kediri”. Jurnal Keuangan dan Perbankan (Januari), hal 31-33.

Ikatan Akuntan Indonesia (IAI). 2009. Pernyataan Standar Akuntansi Keuangan (PSAK) No. 1: Penyajian Laporan Keuangan. Jakarta: Salemba Empat.

Indriantoro, Nur dan supomo. 2009. Metodologi Penelitian Bisnis. Yogyakarta: BPFE.

Keputusan Menteri Nomor 96 Tahun 2004 tentang Pedoman Standar operasional Manajemen Koperasi Simpan Pinjam dan Unit Simpan Pinjam Koperasi.

Kurniawati, Indah. 2011. Petunjuk Praktikum Pengolahan Data Elektronik. Yogyakarta: Universitas Ahmad Dahlan.

Munawir. 2002. Akuntansi Keuangan dan Manajemen. Yogyakarta: BPFE UGM.

Panggabean, Riana. 2005. Efektivitas Program Dana Bergulir Bagi Koperasi dan UKM. Infokop No 26 Tahun xx 2005, hal.1.

Peraturan Gubernur Daerah Istimewa Yogyakarta Tahun 2009 tentang Pedoman Pengelolaan Dana Bergulir.

Peraturan Menteri Keuangan Nomor 218 Tahun 2009 tentang Pedoman Pengelolaan Dana Bergulir pada Kementrian Negara/Lembaga.

Pusat Bahasa. 2008. Kamus Besar Bahasa Indonesia. Jakarta: Balai Pustaka

Rudianto. 2006. Akuntansi Koperasi. Jakarta: Grasindo

Setiawan, Achmad Hendra dan Rejekiningsih Triwahyu. 2009. "Dampak Dana Bergulir Bagi Usaha Kecil dan Menengah (UKM)". Jurnal Ekonomi. Hal 111-114. 
lebih besar kepada si miskin. Menurut mereka, satu-satunya cara menciptakan mekanisme dari dalam guna meluruskan keputusan-keputusan alokasi yang sangat adil adalah menjadikan rakyat mempunyai pengaruh. Menurut Kartasismita (1996) dikutip dalam Huri et al., (2008: 87) menambahkan bahwa pemberdayaan masyarakat dapat diartikan sebagai upaya untuk membangun daya dengan mendorong, memberikan motivasi, dan membangkitkan kesadaran akan potensi yang dimilikinya serta berupaya untuk mengembangkannya. Variabel pemberdayaan masyarakat dalam penelitian ini adalah dana zakat untuk penguatan ekonomi keluarga dengan diukur berdasarkan 5 skala likert.

\section{Teknik Analisis Data}

\section{Uji Kualitas Data}

Menurut Ghozali (2011: 52) uji validitas digunakan untuk mengukur sah atau tidaknya suatu kuesioner. Suatu kuesioner dikatakan valid jika pertanyaan pada kuesioner mampu untuk mengungkapkan sesuatu yang akan diukur oleh kuesioner tersebut.

Sementara itu, menurut Ghozali (2011: 47) uji reliabilitas adalah alat untuk mengukur suatu kuesioner yang merupakan indikator dari variabel atau konstruk. Suatu kuesioner dikatakan reliabel atau handal jika jawaban seseorang terhadap pernyataan adalah konsisten atau stabil dari waktu ke waktu.

\section{Analisis Regresi Berganda}

Metoda yang digunakan untuk menguji hipotesis penelitian ini dengan menggunakan analisis regresi sederhana. Menurut Ghozali (2011: 96) analisis regresi adalah penggunaan analisis untuk mengukur dua variabel atau lebih, juga menunjukkan hubungan antara veriabel dependen dengan variabel independen. Langkah-langkah dalam regresi linier berganda adalah:

\section{a. Uji Asumsi Klasik}

\section{Uji Normalitas}

Menurut Ghozali (2011: 160) uji normalitas bertujuan untuk menguji dalam model regresi, variabel pengganggu atau residual memiliki distribusi normal. Uji statistik untuk menguji normalitas data dalam penelitian ini menggunakan uji 
Kolmogorov Smirnov dengan tingkat signifikansi sebesar 0,05. jika hasil yang diperoleh lebih besar dari 0,05 maka dapat disimpulkan bahwa data residual tidak berdistribusi normal.

\section{Uji Multikolinearitas}

Menurut Ghozali (2011: 105) uji multikolinearitas bertujuan untuk menguji model regresi ditemukan adanya korelasi antara variabel bebas (independen). Model yang baik seharusnya tidak terjadi korelasi di antara variabel independen. Jika variabel independen saling berkorelasi, maka variabel-variabel ini tidak ortogonal. Ada tidaknya multikolinearitas dalam suatu regresi, dapat dilihat melalui nilai variance inflation factor (VIF) dengan tingkat toleransi sebesar $1 \%(0,10)$.

\section{Uji Heteroskedastisitas}

Menurut Ghozali (2011: 139) uji heteroskedastisitas bertujuan menguji dalam model regresi terjadi ketidaksamaan varian dari residual satu pengamatan ke pengamatan yang lain. Untuk menguji ada tidaknya heteroskedastisitas dengan menggunakan uji Glejser. Gejala heteroskedastisitas dapat dideteksi dengan membandingkan tingkat signifikansi $\alpha=5 \%$ dengan tingkat signifikansi t. Apabila signifikansi t lebih besar dari tingkat signifikansi $\alpha=5 \%$, maka tidak terjadi heteroskedastisitas.

\section{Uji Autokorelasi}

Menurut Ghozali (2011: 110) uji autokorelasi bertujuan menguji dalam model regresi linier ada korelasi antara kesalahan pengganggu pada perioda t dengan kesalahan pengganggu pada perioda t-1 (sebelumnya). Jika terjadi korelasi, maka disebut dengan problem autokorelasi. Pendeteksian ada atau tidaknya autokorelasi dengan menggunakan uji Durbin Watson.

\section{Analisis Statistik Diskiptif}

Menurut Ghozali (2011: 19) statistik diskriptif memberikan gambaran atau diskiptif suatu data yang dilihat dari nilai rata-rata (mean), standar deviasi, varian, maksimum, minimum, sum, range, kurtosis, dan skewness. Tujuan Statistik 
diskiptif pada penelitian ini untuk memberikan gambaran atau deskriptif atas data yang dikumpulkan.

\section{b. Uji Hipotesis}

\section{Koefisien Determinasi (Adjusted R Square)}

Menurut Ghozali (2011: 97) koefisien determinasi $\left(\mathrm{R}^{2}\right)$ pada intinya mengukur kemampuan model dalam menerangkan variasi variabel dependen. Nilai koefisien determinasi adalah antara nol dan satu. Nilai $\mathrm{R}^{2}$ yang kecil berarti kemampuan variabel-variabel independen dalam menjelaskan variasi variabel dependen sangat terbatas. Nilai yang mendekati satu berarti variabel-variabel independen memberikan hampir semua informasi yang dibutuhkan untuk memprediksi variasi variabel dependen.

\section{Uji F}

Menurut Ghozali (2011: 98) uji statistik F pada dasarnya menunjukkan apakah variabel independen yang dimasukkan dalam model mempunyai pengaruh secara bersama-sama terhadap veriabel dependen.

\section{Uji t}

Menurut Gozali (2011: 64) uji statistik t digunakan untuk menentukan apakah dua sampel yang tidak berhubungan memiliki nilai rata-rata yang berbeda.

\section{HASIL DAN PEMBAHASAN}

Tabel 1 menunjukkan bahwa dari 30 responden terdapat 19 pria $(63,3 \%)$ dan 11 wanita $(36,7 \%)$. Umur responden penelitian ini terdiri dari 25-30 tahun sebanyak 1 orang $(3,3 \%), 31-35$ tahun sebanyak 9 orang (30\%), 36-40 tahun sebanyak 8 orang $(26,7), 41-45$ tahun sebanyak 9 orang (30\%), >45 tahun sebanyak 3 orang (10\%). Status perkawinan responden kawin sebanyak 28 orang $(93,3 \%)$ dan belum kawin sebanyak 2 orang (6,7\%). Responden penelitian ini terdiri dari pendidikan SD sebanyak 8 orang (26,7\%), SMP sebanyak 4 orang (13,3\%), SMA 17 orang $(56,7 \%)$, dan $\mathrm{S} 1$ sebanyak 1 orang $(3,3 \%)$. 
Tabel 1

Karakteristik Responden Penelitian

\begin{tabular}{|c|c|c|c|c|c|}
\hline Karakteristik & Jumlah & $\%$ & Karakteristik & Jumlah & $\%$ \\
\hline $\begin{array}{c}\text { Jenis Kelamin } \\
\text { Pria }\end{array}$ & 19 & 63,3 & Status Perkawinan & & \\
Wanita & 11 & 36,7 & Kelum kawin & 28 & 93,3 \\
\hline Jumlah & 30 & 100 & Jumlah & 30 & 100 \\
\hline Umur & & & Pendidikan & & \\
$25-30^{\text {th }}$ & 1 & 3,3 & SD & 8 & 26,7 \\
$31-35^{\text {th }}$ & 9 & 30 & SMP & 4 & 13,3 \\
$36-40^{\text {th }}$ & 8 & 26,7 & SMA & 17 & 56,7 \\
$41-45^{\text {th }}$ & 9 & 30 & S1 & 1 & 3,3 \\
$>45^{\text {th }}$ & 3 & 10 & & & \\
\hline Jumlah $^{\text {Sum }}$ & 30 & 100 & Jumlah & 30 & 100 \\
\hline
\end{tabular}

Sumber: Data primer, diolah (2014)

\section{Uji Instrumen Penelitian}

Berdasar uji validitas dapat dilihat bahwa masing-masing item pertanyaan memiliki nilai $r$ hitung $>r$ tabel $(0,361)$. Sehingga dapat disimpulkan semua item pertanyaan dinyatakan valid. Sementara itu, uji reliabilitas menunjukkan bahwa seluruh variabel penelitian memberikan nilai cronbach alpha lebih besar dari 0,07, yang artinya reliabel.

\section{Uji Asumsi Klasik}

\section{Uji normalitas}

Hasil uji normalitas pada tabel 2 menunjukkan nilai Kolmogorov Smirnov 0,833 yang lebih besar dari 0,05. Berdasar hasil tersebut, diketahui bahwa data berdistribusi normal.

Tabel 2

Uji Normalitas

\begin{tabular}{|l|l|}
\hline Uji Kolmogorov-smirnov & Unstandarize Residual \\
\hline Nilai Kolmogorov-Smirnov & 0,623 \\
\hline Sig & 0,833 \\
\hline
\end{tabular}

Sumber: Data primer, diolah (2014) 


\section{Uji Multikolinieritas}

Hasil pengujian multikolinieritas yang menunjukkan nilai variance inflation factor (VIF) variabel, yaitu pendayagunaan zakat produktif adalah 1,000 yang lebih kecil dari 10. Berdasar hasil tersebut, diketahui bahwa antar variabel independen tidak terjadi persoalan multikolinieritas.

Tabel 3

Uji Multikolinearitas

\begin{tabular}{|l|c|c|}
\hline \multirow{2}{*}{ Model } & \multicolumn{2}{|l|}{ Collinearity Statistics } \\
\cline { 2 - 3 } & Tolerance & VIF \\
\hline $\begin{array}{l}\text { 1 (Constant) } \\
\text { Penggunaan } \\
\text { Dana Zakat }\end{array}$ & 1.000 & 1.000 \\
\hline
\end{tabular}

Sumber: Data primer, diolah (2014)

\section{Uji Heteroskedastisitas}

Berdasar nilai VIF untuk variabel penggunaan dana zakat terhadap pemberdayaan masyarakat sebesar $1.000<5$. Berdasar hasil tersebut, diketahui bahwa model tersebut tidak ada multikolinearitas.

Tabel 4

Uji Heteroskedastisitas

\begin{tabular}{|c|l|l|l|l|}
\hline & & & \multicolumn{2}{|c|}{$\begin{array}{c}\text { Collinearity } \\
\text { Statistics }\end{array}$} \\
\cline { 3 - 5 } Model & $\mathbf{t}$ & Sig. & Tolerance & VIF \\
\hline $\begin{array}{c}\text { 1 (Constant) } \\
\text { Penggunaan } \\
\text { dana zakat }\end{array}$ & 1.593 & .122 & 1.000 & 1.000 \\
\hline
\end{tabular}

Sumber: Data primer, diolah (2014)

\section{Uji Autokorelasi}

Hasil pengujian dengan menggunakan uji Durbin-Watson atas residual persamaan regresi, diperoleh nilai Durbin Watson 1,603. Sedangkan nilai dL dan dU dari tabel Durbin-Watson dengan $\alpha=5 \%, n=30$ dan $\mathrm{K}=2$ menunjukkan nilai $\mathrm{dL}=1,255$ dan $\mathrm{dU}=1,560$. Nilai $4-\mathrm{dL}=4-1,255=2,745$ dan nilai 4-dU=4-1,560= 2,44. Dengan demikian, diketahui bahwa tidak terdapat autokorelasi. 
Tabel 5

Uji Autokorelasi

\begin{tabular}{|c|c|c|c|c|c|}
\hline Model & $\boldsymbol{R}$ & $\boldsymbol{R}$ Square & $\begin{array}{c}\text { Adjusted } \boldsymbol{R} \\
\text { Square }\end{array}$ & $\begin{array}{c}\text { Std. Error of } \\
\text { the Estimate }\end{array}$ & $\begin{array}{c}\text { Durbin- } \\
\text { Watson }\end{array}$ \\
\hline 1 & $.486^{\mathrm{a}}$ & .236 & .209 & 7,187 & 1,603 \\
\hline
\end{tabular}

Sumber: Data primer, diolah (2014)

\section{Uji Hipotesis}

\section{Koefisien determinasi $\left(\mathbf{R}^{2}\right)$}

Hasil koefisien determinasi meunjukkan nilai $\mathrm{R}$ sebesar 0,236 yang berarti kemampuan veriabel penggunaan dana zakat terhadap pemberdayaan masyarakat kurang baik karena nilai yang diperoleh kuarang dari sattu. Hasil adjusted $R$ square sebesar 0,209 atau 20,9\% faktor yang mempengaruhi pemberdayaan masyarakat dapat dijelaskan oleh faktor penggunaan dana zakat. Sedangkan 79,1\% (100\%20,9) dipengaruhi oleh faktor lain yang tidak diteliti.

Tabel 6

Koefisien Determinasi

\begin{tabular}{|l|l|l|l|l|l|}
\hline Model & $\boldsymbol{R}$ & $\boldsymbol{R}$ Square & $\begin{array}{l}\text { Adjusted } \\
\boldsymbol{R} \text { Square }\end{array}$ & $\begin{array}{l}\text { Std. Error of } \\
\text { The Estimate }\end{array}$ & $\begin{array}{l}\text { Durbin- } \\
\text { Watson }\end{array}$ \\
\hline 1 & .486 & .236 & .209 & 7,187 & 1,603 \\
\hline
\end{tabular}

Sumber: Data primer, diolah (2014)

\section{Analisis Regresi}

Pengujian penggunaan dana zakat terhadap pemberdayaan masyarakat ini akan menunjukkan bahwa penggunaan dana zakat berpengaruh terhadap pemberdayaan masyarakat, adapun pengujian statistik menggunakan SPSS dengan menggunakan alpa $(\alpha)$ sebersar 5\% sebagai berikut:

Tabel 7

Anova

\begin{tabular}{|c|c|c|c|c|c|}
\hline Model & Sum of Squares & $\boldsymbol{d} \boldsymbol{f}$ & Mean Square & $\boldsymbol{F}$ & Sig. \\
\hline Regression & 447.592 & 1 & 447.592 & 8,665 &, 006 \\
Residual & 1446.408 & 28 & 51.657 & & \\
Total & 1894.000 & 29 & & & \\
\hline
\end{tabular}

Sumber: Data primer diolah, 2014 
Tabel anova menunjukkan hasil perhitungan f hitung sebesar 8,665 dengan tingkat signifikansi $0,006>\alpha$ yaitu sebesar 0,05. Dengan demikian, diketahui bahwa terdapat pengaruh yang signifikan antara variabel penggunaan dana zakat terhadap pemberdayaan masyarakat.

Hasil perhitungan statistik ordinary least square (OLS) ditunjukkan dengan t hitung. Secara terperinci hasil t hitungdijelaskan dalam tabel berikut:

\section{Tabel 8}

Coefficients

\begin{tabular}{|c|c|c|c|c|c|c|c|}
\hline \multirow{2}{*}{ Model } & \multicolumn{2}{|c|}{$\begin{array}{c}\text { Unstandardized } \\
\text { Coefficients }\end{array}$} & \multirow{2}{*}{\begin{tabular}{|l|}
$\begin{array}{r}\text { Standardized } \\
\text { Coefficients }\end{array}$ \\
Beta \\
\end{tabular}} & \multirow[b]{2}{*}{$t$} & \multirow[b]{2}{*}{ Sig. } & \multicolumn{2}{|c|}{$\begin{array}{l}\text { Collinearity } \\
\text { Statistics }\end{array}$} \\
\hline & B & $\begin{array}{c}\text { Std. } \\
\text { Error }\end{array}$ & & & & Tolerance & VIF \\
\hline $\begin{array}{l}1 \text { (Constant) } \\
\text { Penggunaan } \\
\text { dana Zakat }\end{array}$ & $\begin{array}{r}20,089 \\
1,294 \\
\end{array}$ & $\begin{array}{r}12,608 \\
, 439 \\
\end{array}$ & ,486 & $\begin{array}{l}1,593 \\
2,944\end{array}$ & $\begin{array}{l}, 122 \\
, 006 \\
\end{array}$ & 1.000 & 1.000 \\
\hline
\end{tabular}

Sumber: Data primer, diolah (2014)

Hasil penghitungan t hitung menunjukkan nilai t hitung menunjukkan bahwa nilai t hitung 2,944 dengan tingkat signifikansi 0,006 yang dibawah alpha yaitu sebesar 0,05. Dengan demikian, diketahui bahwa terdapat pengaruh yang signifikan antara variabel penggunaan dana zakat terhadap pemberdayaan masyarakat. Tabel 8 dapat diketahui hasil analisis regresi diperoleh koefisien untuk veriabel penggunaan dana zakat sebesar 1,294 dengan konstanta sebesar 20,089 sehingga dapat dibuat model persamaan regresi sebagai berikut:

\section{$Y=20,089+1,294 X$}

Berdasar persamaan regresi dapat diprediksi bahwa veriabel dependen akan berubah sebesar 1,294 untuk setiap unit perubahan yang terjadi pada veriabel independen. Akan tetapi dari hasil penelitian ini dapat disimpulkan bahwa variabel penggunaan dana zakat berpengaruh secara signifikan terhadap pemberdayaan masyarakat. 


\section{SIMPULAN, KETERBATASAN, DAN SARAN}

Berdasar hasil penelitian yang telah dilakukan mengenai pengaruh antara penggunaan dana zakat terhadap pemberdayaan masyarakat pada Badan Amil Zakat dan Lembaga Amil Zakat di Yogyakarta, maka dapat ditarik simpulan bahwa terdapat pengaruh antara penggunaan dana zakat terhadap pemberdayaan masyarakat pada Badan Amil Zakat dan Lembaga Amil Zakat di Yogyakarta. Keterbatasan dalam penelitian ini adalah sedikitnya data yang digunakan dalam penelitian karena Badan Amil Zakat dan Lembaga Amil Zakat belum banyak yang melaksanakan program pemberdayaan masyarakat.

Beberapa saran yang berkaitan dengan penelitian ini antara lain:

1) Bagi lembaga pengelola zakat

Hasil penelitian yang telah dilakukan bahwa penggunaan dana zakat mempunyai pengaruh terhadap pemberdayaan masyarakat. Sehingga penelitian ini dapat digunakan lembaga pengelola zakat agar dana zakat yang di peroleh dapat alokasikan untuk pemberdayaan masyarakat.

2) Bagi penelitian selanjutnya

Penelitian ini diharapkan dapat dikembangkan lagi dengan menambahkan variabel seperti tranparansi laporan keuangan penggunaan dana zakat dan perluasan konsep pemberdayaan masyarakat.

\section{DAFTAR PUSTAKA}

Anwas, Oos M. 2013. Pemberdayaan Masyarakat di Era Global. Bandung: Alfabeta.

Ardhanareswari, Resti. 2010. Analisis Sumber dan Penggunaan dana Zakat yang Berpengaruh terhadap Pemberdayaan Masyarakat. Bandung: Universitas Komputer Indonesia.

Asnaini. 2008. Zakat Produktif dalam Prespektif Hukum Islam. Yogyakarta: Pustaka Pelajar

Berita Ramadhan. 2012. [Online] Didapatkan: http://ramadhan.antaranews.com [17 februari 2014] 
Ghozali, Imam. 2011. Aplikasi Analisis Multivariate dengan Program IBM SPSS 19. Semarang: Universitas Diponegoro.

Hadi, Muhammad. 2010. Problematika Zakat Profesi dan Solusinya (Sebuah Tinjauan Sosiologis Hukum Islam). Yogyakarta: Pustaka Pelajar.

Hafidhuddin, Didin. 2008. Panduan Praktis tentang Zakat, Infak dan Sedekah. Jakarta: Gema Insani.

Hafidhuddin, Didin. 2002. Zakat dalam Perekonomian Modern. Jakarta: Gema Insani.

Huri, Daman, Moh. Miftahusyaian, Ronald J Warsa, Sutomo, dan Yudha Aminta. 2008. Demokrasi \& Kemiskinan. Malang: Averroes Press.

Ikatan Akuntansi Indonesia. 2011. Pernyataan Standar Akuntansi Keuangan No. 11 dan 70: Laporan Sumber dan Penggunaan Dana Zakat [online]. Didapatkan: http://www.iaiglobal.or.id [16 November 2013]

Indriantoro, Nur dan Bambang Supomo. 2012. Metodologi Penelitian Bisnis untuk Akuntansi dan Manajemen. Yogyakarta: BPFE UGM.

Muhammad. 2005. Pengantar Akuntansi Syariah. Jakarta: Salemba Empat.

Muhammad, Sahri, 2006. Mekanisme Zakat dan Permodalan Masyarakat Miskin, Malang: Bahtera Press.

Nurhayati, Sri dan Wasilah. 2012. Akuntansi Syariah di Indonesia. Jakarta: Salemba Empat.

Permendagri No.7 Tahun 2007: Kader Pemberdayaan Masyarakat [Online]: Didapatkan: http://agus34drajat.files.wordpress.com [Juni 2014]

Prastiya, Sulih, 2010, Kebijakan Kementrian Agama dalam Manajemen Zakat [Online]. Didapatkan: http://baznas.jogjakota.go.id [24 April 2014]

Putra, Ahmad Fajri. 2010. Pengaruh Pendayagunaan Zakat Produktif Terhadap Pemberdayaan Mustahiq Pada Badan Pelaksana Urusan Zakat Amwal Muhammadiyah (BAPELURZAM) Pimpinan Cabang Muhammadiyah 
Weleri Kabupaten Kendal. Skripsi. Semarang: IAIN Walisongo.

Putri, Niken Iwani Surya, 2012, Hikmah Keislaman [Online]. Didapatkan: https://ppmrindonesia.wordpress.com [16> November 2013]

Soemitra, Andri. 2009. Bank dan Lembaga Keuangan Syariah. Jakarta: Kencana.

Sugiyono. 2008. Metode Penulisan Kuantitatif, Kualitatif dan R\&D. Bandung: Alfabeta.

Undang-Undang Nomor 23 Tahun 2011: Pengelolaan Zakat [Online]. Didapatkan: http://lampung.kemenag.go.id [17 November 2013]

Utomo, Setiawan Budi. 2009. Metode Praktis Penetapan Nisab Zakat: Model Dinamis Berdasarkan Standar Nilai Emas dan Kebutuhan Hidup Layak (KHL) Provinsi. Bandung: Mizan Pustaka. 